A NORWEGIAN GREY ZONE: KNUT RØD, VICTOR LIND AND “THE CRUCIAL YEAR, 1942”

p. 155

\title{
ABSTRACT
}

This article uses Primo Levi's concept of "the grey zone” to explore Knut Rød's involvement in the transfer of 532 Norwegian Jews from Oslo to Auschwitz in 1942. Rød, the police chief in charge of the operation, was subsequently exonerated of any crime on the grounds that he had simultaneously used his position to help members of Milorg - the Norwegian Resistance. The legal and moral basis of this verdict has been questioned by the artist Victor Lind in a series of artworks, including his “countermonument” The Perpetrator (2005).

Keywords: commemoration; countermonument; Holocaust; Levi, Primo; Lind, Victor; memory; Norway; Rød, Knut

\section{THE GREY ZONE}

"THE FIRST NEWS about the Nazi annihilation camps began to spread in the crucial year, 1942." So begins Primo Levi's final book, The Drowned and the Saved, the second chapter of which serves as the touchstone for the present article.[1] Its title "The Grey Zone" - refers to the state of affairs Levi encountered at Auschwitz.[2] He wrote that, rather than sanctifying its victims, the concentrationary system triggered a "moral collapse" resulting in a blurring of the dividing line between "us" and "them". The struggle for survival that ensued gave rise to the people of the grey zone: those "prisoners who in some measure, perhaps with good intentions, collaborated with the authority" (DS, 9). At their most extreme these individuals were either "obscene" or "pathetic". Most manifest aspects of both characteristics (DS, 25). This reflected the "infinite nuances and motivations" behind every act of complicity. The one unifying feature was the desire to obtain and maintain some sort of privilege (DS, 28). For many, the acquisition and preservation of such an advantage was an essential means of survival.

The "frightful" pressure of living under a totalitarian system (DS, 16) meant that resistance "from below" was "almost impossible" (DS, 31). Yet that it was almost out of the question was crucial. Levi declared that there were "a thousand ways [...] to manifest one's solidarity with the oppressed" (DS, 148). So, whilst Levi wished to "absolve all those whose concurrence in the guilt was minimal" (DS, 29), he rejected unconditionally the notion that the categories of "oppressor and victim" were somehow interchangeable (DS, 32). Those that sought to

\section{p. 156}

collapse the distinction between them were, in Levi's opinion, "negators of truth" because "confusing the two roles" meant fundamentally "becloud[ing] our need for justice" (DS, 33). Nevertheless, this search for the truth is complicated by the fact that 
"[w]e cannot judge our behaviour or that of others, driven at that time by the code of that time, on the basis of today's code" (DS, 61; cf. DS, 135).

The pervasiveness of the grey zone, the extreme difficulty of applying the moral code of one situation to that of another, and the pressure of living under a totalitarian system means - as Levi so consummately demonstrates - that coming to judgement is as difficult as it is necessary. The latter motivation lies at the heart of Levi's final book. Its overarching goal is to prevent "the concentration camp world" from returning (DS, 9). And it is for this reason that the unpleasant but very necessary task of "[dredging] this abyss of viciousness" must be undertaken, "because what it was possible to perpetrate yesterday can be attempted again tomorrow" (DS, 37). The examination of figures that occupied the grey zone is essential "if we want to know how to defend our souls when a similar test should once more loom before us" (DS, 26).

This has important repercussions for an understanding of "History" and the role that the past should play in the present. Levi disavowed the idea that "human history is a deterministic process" and argued that "simplifications are proper only for textbooks, the whys can be many, entangled with one another or unknowable, if not actually nonexistent” (DS, 122). He therefore cautioned against the tendency for individuals and societies to "simplify" the past and claimed that "popular history, and also the history taught in schools [. . .] shuns half-tints and complexities" (DS, 22). This is implicitly contrasted with what might be termed "academic history”, as when Levi writes:

"the pattern within which events are ordered is not always identifiable in a single unequivocal fashion, and it may therefore happen that different historians understand and construe history in ways that are incompatible with one another.” (DS, 22)

Distinctions between "popular" and "academic" history, however, are far from clear cut. In fact, museums as manifestations of "popular history" are eminently capable of articulating the dissonance that is arguably the hallmark of an apparently more narrowly prescribed, "scholarly" history. Indeed, it might well be the case that, on occasions, an action outside the discipline of "History" can provoke the most profound challenge to collective understandings of the past. A very fine example of this is the work of the Norwegian artist Victor Lind (born 1940). Two artworks in particular play out Levi's distinctions between the "half-tints and complexities" of academic history and the supposedly less nuanced, "unequivocal” traits of "popular" history. Taken together they address the Levian grey zone in an extremely thoughtprovoking manner.

p. 157

\section{CONTEMPORARY MEMORY}

Contemporary Memory - Who is Afraid? is an art installation dating from the year 2000. It utilises image, text and sound to create a square formed out of four video screens. Three of the four relate to a legal proceeding. On one appear quotations from a court trial. A second features texts giving the judiciary's reasons for finding the accused not guilty. The third gives the "official” history of the trial as seen from the 
perspectives of various historians. The remaining screen presents extracts of Paul Celan's "Psalm" from Die Niemandsrose of 1963.[3] An overall soundtrack is provided in the form of a remixed, toned-down version of Solitaire, composed in 1968 by Arne Nordheim (born 1931).

Visible behind the text on each screen is a film sequence lasting seven minutes, twenty seconds. It plays in a continuous loop and shows a procession of one hundred taxis forming a very long line down a broad, straight street (see Figure 1). The car headlights gleam in the early-morning darkness. These taxis had gathered at the behest of the artist, Victor Lind, and the film he shot of them was subsequently incorporated into the work Contemporary Memory - Who is Afraid?

In assembling the taxis, Lind was consciously echoing an event that took place 56 years earlier at exactly the same place, at the same hour of the day, on the same day of the week, and in the same month of the year. That was 4:30 in the morning on Thursday, 26 November “in the crucial year, 1942”.[4] The place

[Figure 1: Video still from Contemporary Memory - Who is Afraid?, by Victor Lind.]

p. 158

was Kirkeveien in central Oslo. Each of the one hundred taxi drivers had been given a police escort and provided with an address of a Jewish resident of Oslo. They were instructed to go there, announce their arrival and wait for the identified residents to get dressed and gather a few possessions together before being driven to the harbour. The operation was meticulously planned. The early hour was chosen in order to ensure that as many people as possible were at home. The police, operating under the cover of darkness, were instructed to act with calm restraint so as not to awaken any disquiet. By the conclusion of this and other operations,[5] some 532 men, women and children had been delivered to the harbour. It was only then that they were handed over to the Germans. Up to that point the action had been carried out by the Norwegian police operating under orders from the Nazi authorities.

The police on the ground were led by Knut Rød (1900-86). He had joined the Statspolitiet (STAPO, the State Police) in July 1941 and rose to the post of politiinspektør as head of the Oslo-Aker district one year later.[6] He went on to have a successful post-war career, serving as divisional chief in the Oslo police until his retirement in June 1965. This was despite the fact that he was implicated in what has been called the most "shameful chapter in Norwegian history".[7] This relates to those ill-fated people who found themselves at the quayside early in the morning of 26 November 1942. From there they were shipped to Auschwitz where all but eleven of them died.

Rød did not deny his involvement in the events of November 1942. He admitted to leading the well-coordinated police action. Whilst his subordinates were Norwegian, Rød stressed that he was acting under directions sent down by his superiors. At his post-war trial, the accused claimed that he had had no choice other than to cooperate with his Nazi taskmasters. Refusal might have put at jeopardy his post as politiinspektør. He argued that this position was vital to his other, clandestine, duties namely his support for Milorg, the armed resistance movement in Norway. 
It is on these terms that Knut Rød can be included in the list of "camouflaged opponents" identified by Primo Levi in "The Grey Zone”. These were individuals whose complicity with the Nazi authorities was "counterbalanced" by their membership of "secret defence organisations" (DS, 30). Rød collaborated with the occupying enemy, but was he a "traitor"?[8] Did he, paradoxically enough, collaborate with the Nazis precisely in order not to betray his homeland? How should a "traitor" be so defined? Who are we to sit in judgement on people who acted in very different and very difficult circumstances? How would we have behaved in a similar situation? Is Rød a villain of the Holocaust or a hero of the Resistance? Was he, perhaps, both a Nazi and a patriot?[9]

The answers to these and related questions are skewed by the fact that "[t]he first news about the Nazi annihilation camps began to spread in the crucial year, 1942". How much was known in Norway about the true import of the "final solution" outlined at Wannsee on 20 January 1942? Was Knut Rød aware that he would, however indirectly, be responsible for the deaths of so many people?

p. 159

Was he an active participant or a subordinate obeying orders? These enquiries get to the essence of what Levi meant when he commented on the "half-tints and complexities" of history, none of which can be answered "in a single unequivocal fashion”.

Knut Rød is a grey-zone character par excellence. He was never a "formal” member of Milorg.[10] In 1943 he resigned both his post as politiinspektør and his membership of the Nazi party.[11] Was this one of the "thousand ways... to manifest one's solidarity with the oppressed” identified by Primo Levi? At his post-war trial, it was asserted that Rød had passed on information to the Norwegian Resistance, although the exact nature of this was never determined. His acquittal was partly based on the evidence of men who were themselves implicated in the events of 26 November 1942.

It is in the context of this infinitely complex grey zone that a fundamental question arises: were the deaths of so many innocent people a price worth paying? Without their "sacrifice", would the valuable role performed by the resistance movements in occupied Norway have been seriously curtailed or fatally compromised? Would it have mattered if, on 26 November 1942, Knut Rød had arranged for 532 Norwegian students or teachers to be transported to the death camps?[12] If there is a difference, what does that say about those residents of Norway in 1942 who happened to be Jewish? Were they somehow less "Norwegian" and therefore expendable? Are the answers to these questions the same in the year 1948 at the time of Rød's trial as they were in 1998 when Lind arranged his homage of taxis? What will the Norwegians alive on 26 November 2042 make of the events of a century before? Will they even be remembered?

These and many other questions emerge out of the "parallel histories" that Victor Lind shapes in his artwork, Contemporary Memory - Who is Afraid?[13] The four synchronised video sequences with their divergent narratives are projected on to 
separate walls. The viewer stands in the middle, turning from one screen to another. It is Lind that has edited and presented the narratives, but it is left to us, the viewers, to interpret what we see. We do so from our personal perspective and our "today". In this work Lind brings the past into the present: whenever it is shown in a gallery, it will be projected into the consciousness of individual visitors. This is the first meaning of the title - Contemporary Memory. But there is another sort of "present" inherent in this piece, one that is already history. Rather than film footage or images from 1942, Lind uses something that dates from 1998 - the film he took of the taxis lining up along Kirkeveien. This commemorative action serves as an intermediary stage, bridging today with a recent past that in turn references something that seems so long ago. Lind uses many strategies for enacting the past, not least in the carefully chosen day, date, time and place of his re-enactment. This produces something that is as resonant with contemporary concerns as it is with strictly historical issues. Lind combines distant shots of the taxis with close-ups of the drivers, many of whom come from ethnic minorities. By inserting the past in the present, Lind

\section{p. 160}

is prompting as many questions about discrimination and persecution in contemporary Norwegian society as in Norway under Nazi occupation. Lind's perspicacity in this seemed to be confirmed on 26 November 2002 when a police operation across Norway was initiated to identify illegal immigrants. Lind remarked on the "grotesque" timing of this "anniversary".[14] Yet this distastefulness is contingent on the police action being consciously timed to coincide with the events of 26 November 1942. If, instead, the authorities were ignorant of the date, then this can be read as "historylessness" writ large. The events that took place in Oslo on November 26 "in the crucial year, 1942” had been forgotten.

\section{THE PERPETRATOR}

In The Drowned and the Saved, published forty years after the end of the Second World War, Levi expressed his fear that the experience of the Nazi camps was becoming "ever more extraneous as the years pass" (DS, 166). Levi himself provided one means of countering this when he acknowledged the role monuments and ceremonies play in retaining the presence and pertinence of the past. He somewhat grudgingly conceded that such "rhetoric is perhaps indispensable for the memory to persist” (DS, 8). This, Levi went on to explain, is because individual human memory is "fallacious", susceptible to change by time and intervening events such that certain memories get "erased" whilst others "increase". Levi juxtaposes this fecklessness with the type of memory that is "carved in stone" (DS, 11).

Victor Lind both confirms and questions this view in his numerous Rød-inspired artworks. Contemporary Memory - Who is Afraid?, for instance, demonstrates an inventive and challenging example of the multiple intrusions of the past into the present. It is not a straightforward act of commemoration. Nor is the work that is in many ways its foil. This is the monument he created in 2005, to date the piece that has awakened most attention (see Figure 2).[15] It takes the form of a traditional figurative bronze statue on a granite pedestal, the four sides of which each carry an 
inscription "carved in stone". The one which appears on the front reads, in translation:[16]

"Police inspector / KNUT RØD / 1900-1986 / Head of the State police in Oslo / Member of the Nazi Party // Organized the arrests / of the Jews in the Oslo area / who were / transported to Auschwitz / 26 November 1942 // Acquitted by the Norwegian justice system 1948 / Served in the Oslo Police until 30 June 1965”

These are the basic facts of the matter. But, as Levi states, such descriptive statements of fact are "of little interest". Rather it is to the serial "motivations and justifications" behind every action that attention should turn (DS, 13). And this is exactly what Lind does in a further text inscribed into another face of the pedestal. It is an extract from the concluding judgement in the 1948 trial. The court found Rød innocent on the grounds that:

p. 161

[Figure 2: Monument to Knut Rød (The Perpetrator 2005), by Victor Lind.]

p. 162

"Actions, which separately may be seen as acts of assistance to the enemy, were necessary in order to execute the other far more significant acts of resistance. He has all the time followed his plan to damage the enemy and assist his countrymen.”[17]

The legality of this finding was first questioned in an article written four years before the publication of Primo Levi's The Drowned and the Saved.[18] But it is Victor Lind who has done more than any other person to bring the Rød case into the public domain.[19] This challenges Levi's idea that academic History alone is capable of addressing the grey zone or dealing with "half-tints and complexities". However, whilst the "parallel histories" of Contemporary Memory - Who is Afraid? places Knut Rød firmly within the ambit of the grey zone, Lind's monument of 2005 is explicit about the police officer's guilt and the failure of Norway's judicial system to bring him properly to account. Lind has chosen to depict Rød in the uniform of a rank-andfile member of the Statspolitiet, with his right arm raised in salute. The "realism" of the figurative statue is undermined by the fact that it shows Rød (a high-ranking civil servant or embedsmann) attired in an outfit that he rarely - if ever - wore and in the process of making a gesture that he might never actually have made.[20] Lind nevertheless has sought to "expose" him as a Nazi: he is shown, as it were, inside out - the decisions he made, as well as the actions he did and did not take, are written on his body. He is a Nazi in thought and deed. Rød's guilt is underscored by Lind's "signature" which appears on one of the pedestal's four sides. It states:

“The monument stands until the sentence of 9 April 1948 is annulled. Victor Lind.”

This is, therefore, a deliberately "problematic monument".[21] It is a commemorative memorial, but not in a celebratory sense. A subject is remembered, but not in a positive manner. Victor Lind's statue of Knut Rød can be understood as a “countermonument”. James E. Young coined this term to describe the emergence in the 1980s of "brazen, painfully self-conscious memorial spaces conceived to 
challenge the very premises of their being”.[22] Noam Lupu, following on from Young, has more recently added that countermonuments are usually intended "to be ephemeral rather than permanent, to deconstruct rather than displace memory, to be antiredemptive”.[23] This could easily serve as a description of Lind's monument to Knut Rød.

It was inaugurated in November 2006 - 64 years after Knut Rød assembled his taxis along Kirkeveien and eight years after Victor Lind did the same thing for Contemporary Memory - Who is Afraid? The work was sited, on a temporary basis, at Villa Grande on the peninsula of Bygdøy, a short distance from central Oslo. In this location it constituted a countermonument within a countermonument: Villa Grande was the one-time home of Vidkun Quisling, Minister President of Nazi-occupied Norway from February 1942 until his arrest on 9 May 1945 and subsequent execution. Today it houses The Center for Studies of Holocaust and Religious Minorities ( $H L$ senteret). At its inauguration, the statue received the title

\section{p. 163}

The Perpetrator (Gjerningsmannen), a further confirmation of Lind's unequivocal stance towards Knut Rød.

\section{THE PERPETRATED}

Lind's monument is undoubtedly a striking work. It generated a great deal of debate evidence, perhaps, that Primo Levi's view that the reality of the Nazi camps is becoming "ever more extraneous as the years pass" may be overstated. It helps surmount a sense of numbness brought on by the enormity and incomprehensibility of genocide.[24] Lind's monument is therefore a "success", even if it has not yet achieved its ultimate goal of annulling Rød's trial.[25] Yet The Perpetrator is open to criticism. Its title, depiction and authorial interpretation all serve to lift Knut Rød out of the grey zone entirely. It is a far less nuanced work than Contemporary Memory Who is Afraid? As such, and given the complexities of the grey zone, it is open to an accusation of treating a complex historical event with "excessive simplification". This was something that Primo Levi warned against in The Drowned and the Saved (DS, 9). Even so, Lind's monument might be seen as an embodiment of what Levi himself recognised, namely that "without profound simplification the world around us would be an infinite, undefined tangle that would defy our ability to orient ourselves and decide upon our actions” (DS, 22).

The differences between Contemporary Memory - Who is Afraid? of 1998 and The Perpetrator of 2005 are considerable. Lind himself has provided a rationalisation for the apparent disparity between the multifaceted roundedness of the installation and the pared-down, unmitigated nature of the monument. It is not because of a shift in opinion from doubt to certainty: Lind has always been convinced of Knut Rød's guilt. Yet he was aware that he was operating in an under-researched area. He wished to initiate a discussion and establish a frame of reference. Once the "half-tints and complexities" were established, Lind felt that he was able to make his position explicit.[26] 
There is, however, another explanation for the simplification of The Perpetrator. This is to do with the shortcomings of all so-called "countermonuments". This is best expressed by Noam Lupu, who is sceptical about the radicalism or distinction of the countermonument. For him they have a tendency to be only a "somewhat attenuated formulation of a [conventional] monument”.[27] The Perpetrator is very traditional in formal terms, in that it is a figurative statue cast in bronze mounted on a stepped, stone pedestal. It is in its scale, dedication and intention that Lind's monument runs counter to the norm. Rød is deliberately rendered tiny and pathetic in juxtaposition with the monumental, black, polished-granite pedestal. It is also a countermonument in the sense that this is no official, state-sponsored commission but the work of an individual, committed artist with a personal connection to the "the crucial year, 1942”. For Lind was born in 1940 to a Jewish mother, Lilya Slotnikoff. They were forced to flee to a village 60 kilometres north of Oslo where, thanks to a considerate

\title{
p. 164
}

local official, they managed to avoid the fate that befell $44.8 \%$ of the Jewish population of Norway. Victor Lind and Lilya Slotnikoff could so easily have found themselves on board the Donau on 26 November 1942.

Lupu states that countermonuments seek "to escape the didacticism of the monument”. Nevertheless, Lupu argues, didacticism is still present,

"albeit one that is more attuned to the conflicted discourse of the memory of fascism. This didacticism involves the monument as narrator of an event, a representation of the very event that the counter-memorial project claims cannot be meaningfully represented.”[28]

This holds true for Lind's The Perpetrator. The inscription on the fourth face of the pedestal serves as an echo of the video installation Contemporary Memory - Who is Afraid? and consists of an extract from Paul Celan's "Psalm" from Die Niemandsrose (1963) which reads:

\author{
“A Nothing \\ we were, are now, and ever \\ shall be, blooming: \\ the Nothing-, the \\ No One’s-Rose.”[29]
}

It is an uncomfortable fact that, even in this representation, Knut Rød prevails over the people he conspired to send to their deaths. They remain un-named and anonymous. It is they who are "A Nothing”. Rød is easier to present: he appears ridiculously small on his inflated pedestal. Yet he is represented nonetheless. Lind's monument can therefore be criticised for the fact that the perpetrator is remembered whilst the victims remain in the shadows (cf. DS, 39).[30]

An implicit anxiety surrounding such issues was raised by a book that was published around the same time as the monument's inauguration. This was Espen Søbye's Kathe, alltid vart i Norge ("Kathe, always been in Norway"). Relating the biography of one of the victims of the transportation - Kathe Lasnik (1927-42) - it succeeds in 
giving her an identity, beyond being “just a name on a memorial”.[31] The author stated his wish to erect a different kind of monument to the war ("Eg ville reise eit annleis monument over krigen”).[32] This book is therefore a counter-memorial of a rather different order. However, what Søbye's biography of Kathe Lasnik shares with Lind's earlier Contemporary Memory - Who is Afraid? is the way in which it entered into the present-day debate over immigration (innvandringsdebatt). Kathe Lasnik's story reveals that this is not a new phenomenon.[33] Søbye's account of her plays an important role in blurring the distinction between indigenous and immigrant. In January 1942, the identity cards of all Jews in Nazi-occupied Norway were to be stamped with the letter " $\mathrm{J}$ " and those individuals in possession of such a card were obliged to complete a questionnaire.[34] In answer to the question "When did you come to Norway?", Kathe Lasnik responded: “Always been in Norway." This plaintive honesty forms the title of her belated biography. Its author, Espen Søbye,

\section{p. 165}

speculates at the outset that these words must have been written in an attempt at selfprotection: “I am one of you, surely you wouldn’t do anything to me?”[35]

The fact that this fifteen-year-old girl was so sadly mistaken provides a retort to the verdict in the Knut Rød trial of 1948. How could Kathe Lasnik - who had "always been in Norway" - be extraneous and/or expendable to "other far more significant acts of resistance"? Given Rød's complicity in the death of this innocent Norwegian, how could it be argued that he "all the time followed his plan to damage the enemy and assist his countrymen"? Presumably "all the time" excludes the date 26 November 1942. Kathe Lasnik was born in Oslo on 13 October 1927; she was one of Knut Rød's “countrymen”. And yet she nevertheless met her death in the gas chambers of Auschwitz on 1 December 1942. Only in the most gruesome of senses did politiinspektør Rød “assist” this Norwegian citizen.

\section{FROM STRATEGY TO TACTIC}

Rather than posing “an open question”,[36] Lind's monument presents an (as yet) unfulfilled demand. This is accomplished in a very finely balanced and troubling manner. It wills its own negation and invites iconoclasm in a way that few other monuments do.[37] It is this that needs to be capitalised on. And the best way of achieving this is through its careful placement.

The inscription - "The monument stands until the sentence of 9 April 1948 is annulled" - is a sophisticated appreciation of the mutable meaning of monuments. They do not carry a unitary meaning. Levi was therefore mistaken to contrast memory "carved in stone" with the more "fallacious" human memory (DS, 11). For the former is just as susceptible to changes wrought by time and events. Levi was a chemist and frequently used scientific metaphors. For example he described "states of mind" as "labile" (DS, 17), a word used to describe chemical compounds that are prone to change. One might parallel this with a further chemical metaphor: monuments are akin to catalysts; they are capable of triggering reactions, even if they themselves remain unchanged.[38] Monuments - especially those that seek to commemorate something - can be read and interpreted, re-read and re-interpreted again and again. 
This means that what monuments "mean" (if anything) is largely determined by their physical and temporal context.

That this is the case is clear from the various settings in which Lind's monument has been sited. Its very first public appearance was the austere "white cube" environment of a contemporary art gallery.[39] It took on very different connotations in the resplendent environs of Quisling's Villa Grande, surrounded by the activities of The Center for Studies of Holocaust and Religious Minorities. In many ways this is a very fitting location. But in order to see it one must make a conscious decision to go there. One cannot physically or mentally stumble across it. Equally, those who decide to visit The Center for Studies of Holocaust and Religious Minorities are most unlikely to be the sort of people

\section{p. 166}

who would react negatively to Lind's point of view, even if they do not share his methods or objectives. This sense of consensus and the peripheral location make it lose its visibility and impact. This is doubly unfortunate in the light of James E. Young's remark that "[u]nder the illusion that our memorial edifices will always be there to remind us, we take leave of them and return only at our convenience."[40]

This is particularly problematic given that the monument is currently subject to a further process of marginalisation. Its inauguration in November 2006 was the impetus for a seminar on "the Rød-case", and an explanatory pamphlet was produced featuring the pedestal inscriptions with German and English translations. It was agreed that the monument would be on display for six months. At the end of this period, Lind negotiated an extension. Despite this, it is clear that not all parties involved support the presence of The Perpetrator at The Center for Studies of Holocaust and Religious Minorities.[41] In June 2007 it was moved to the corner of the final room, near the exit leading to the music and mocha of "Café Villa Grande". It is the last thing that the emotionally drained visitor sees. At the time of my visiting (August 2007), it was devoid of any interpretative explanation whatsoever. This is in stark contrast to the "permanent" display which is characterised by a surfeit of text and other media. Compounding this lack is the fact that the monument is placed in the corner of the room, making it difficult if not impossible to read all the inscriptions. Displayed in such a manner, it risks being intelligible only to those with a prior knowledge of both Knut Rød and the work of Victor Lind.

This situation underscores the fact that The Perpetrator demands a very particular sort of location - one that (to mis-recall James Young) is difficult to take leave of, one that obliges us to return to it at our inconvenience. One way to achieve this is by creatively drawing on Michel de Certeau's oft-cited book The Practice of Everyday Life (1984). In it he considers the differences between a "strategy" and a "tactic". The former "assumes a place that can be circumscribed as proper [propre] and thus serves as the basis for generating relations with an exterior distinct from it”.[42] This perfectly characterises The Center for Studies of Holocaust and Religious Minorities: it is an entity that can be "isolated" and thus generate relations with potentially very volatile and difficult issues of genocide and intolerance precisely because they are exterior to it. Lind's monument comes within its orbit - but only just. The monument becomes pacified by being "circumscribed" by the "strategy" that is The Center for Studies of 
Holocaust and Religious Minorities. Those that might be "afraid" of its message (to recall Lind's work Contemporary Memory) can simply avoid going to this institution. And the institution has itself dampened the possibly divisive import of the monument by obscuring its presence at the Center.

It is evident from this that an alternative setting needs to be found for this most challenging of commemorations. One location in particular suggests itself.[43] For there exists another "strategy" analogous to The Center for Studies of Holocaust and Religious Minorities situated in the very heart of Oslo. This is

p. 167 
[Figure 3: The Nobel Peace Center, Oslo.] 


\section{atber}

hines

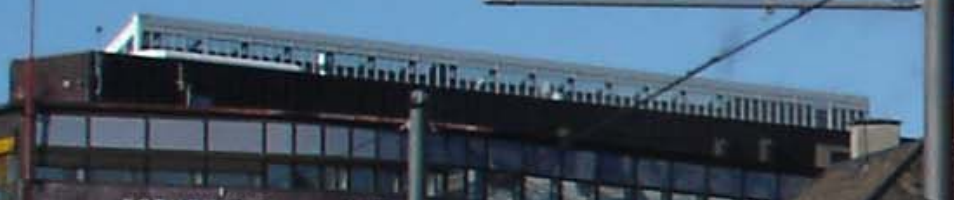

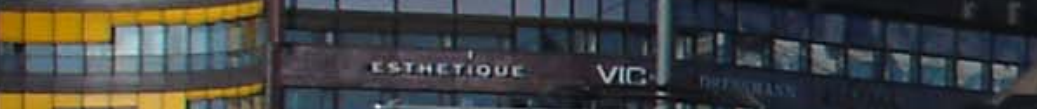
. In Init-

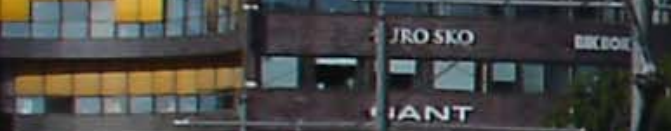

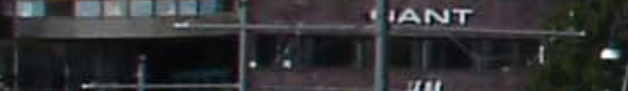

*)

$+10$

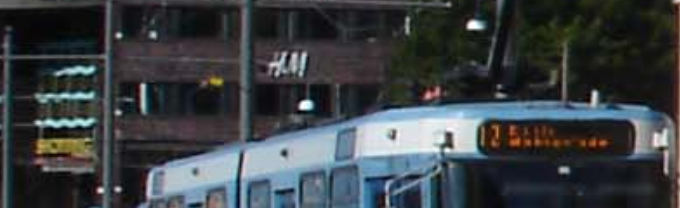

- G $\cos$ (T)

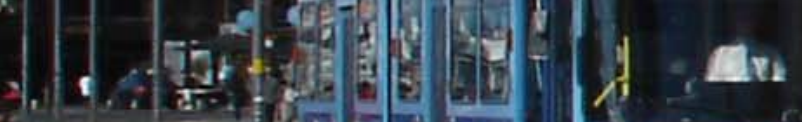

3

23
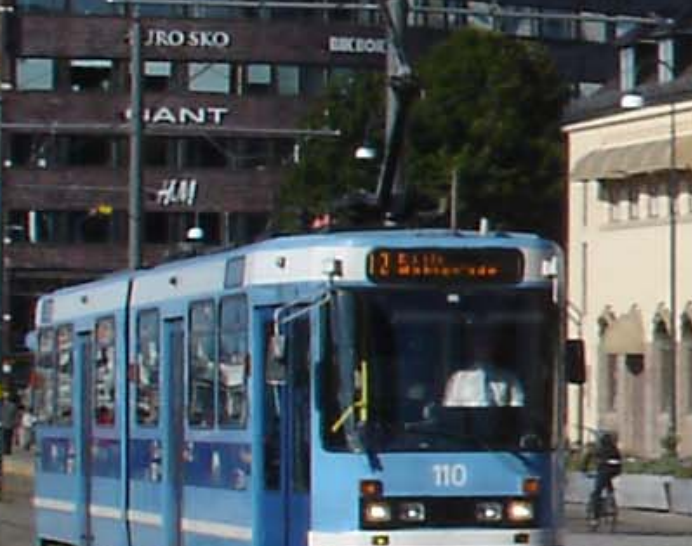

(40) (1) 1

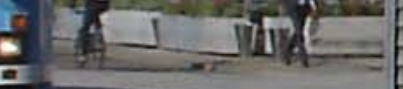


the Nobel Peace Center, inaugurated in 2005 to mark the centenary of Norwegian independence (see Figure 3). Its director, Geir Lundestad, described this institution as "a living centre for communicating the ideals of the Nobel Peace Prize and focusing attention on current conflicts”.[44] It occupies a redundant nineteenth-century railway station and on the main façade are written three words: "broadmindedness" (vidsyn), "hope” (håp) and “commitment” (engasjement).

Now, an asymmetrical position directly outside this institution would realise the full potential of Lind's monument. It could be awkwardly placed between the tram tracks that run past the main façade of the Nobel Peace Center, conveying the sense that this is no compliant, conventional commemoration. The Perpetrator was, however, problematic enough at The Center for Studies of Holocaust and Religious Minorities. It would not be officially tolerated in such a heavily regulated, highly visible and very public location. That this is the case is itself of interest in highlighting the prescribed nature of "public" space. It prompts us to question precisely who it is that decides what should be commemorated, where and how.

A further reason The Perpetrator would not be tolerated outside the Nobel Peace Center is that, sited there, it would become a "tactic" rather than a "strategy". Michel de Certeau says that a "tactic" "insinuates itself into the other's place,

\section{p. 168}

fragmentarily, without taking it over in its entirety, without being able to keep it at a distance".[45] Placed outside the Nobel Peace Center it would in many ways fulfil the essence of Primo Levi's grey zone. Its central location would make it difficult for the public - both residents and tourists alike - to "turn their backs so as not to see it [the Holocaust] and not feel touched by it" (DS, 65); "It happened, therefore it can happen again [...] and it can happen everywhere” (DS, 167). Even Norway - a country that is synonymous with the Nobel Peace Prize and has done so much to resolve conflicts around the world - was not immune. Even here there have been characters in the grey zone. Inside the Nobel Peace Center are the biographies of the worthy winners of the Nobel Peace Prize. But these are the exceptions. What of the far larger number of grey-zone characters, those whose "ambiguity is ours, it is our second nature" (DS, 50)? The presence of Lind's monument would serve as a catalyst, enlivening and complicating the noble aims and intentions of the Nobel Peace Center. It would act as a mediator between "us" (the visitors) and "them" (the Nobel laureates).

Primo Levi described the Nazi camps as an "injury [that] cannot be healed: it extends through time" (DS, 12). The placement of Lind's monument outside the Nobel Peace Center would encapsulate this by establishing a fissure - a grey zone - at the centre of the city. Such a context would be receptive to Victor Lind's monument: the latter's lack of equivocation regarding Rød's culpability would be modulated by an overarching grey zone. In this context, the monument would inspire reflection on the whole gamut of human capabilities ranging between the two extremes of persecutor and humanitarian. Knut Rød occupies an erratic position somewhere along this axis. This would be emphasised should Lind's monument be allowed to tactically occupy a space alongside the strategic Nobel Peace Center. Indeed, it is only in such an environment that it can effectively provide an instance of Contemporary Memory and 
reveal Who is afraid. And more than that it would serve as an effective memorial to Kathe Lasnik and the other Norwegians who found themselves persecuted in "the crucial year, 1942”. For the Nobel Peace Center overlooks Utstikker 1 (Vippetangen) - the quay visited by one hundred taxis in the early hours of 26 November 1942 and from where the ship Donau departed carrying a cargo that should never be forgotten. Because, if it is allowed to elapse, there is a heightened chance of "the concentration camp world" returning - as Primo Levi makes so clear in his final, fundamental book, The Drowned and the Saved.

Victor Lind's monument to Knut Rød, despite its unequivocal stance, has therefore the capacity to elucidate a Norwegian grey zone - but only if it is (in)correctly sited. This is an invaluable and very necessary task. For the issues it tackles are not esoteric matters about the past and of interest only to a few "academic Historians". Instead it is a matter of pressing concern for everyone today. That much is clear from events that took place as this article was being concluded. On Monday 6 August 2007, Ali Haji Mohamed Farah - a 37-year-old Norwegian-Somalian, was attacked in Oslo's Sofienbergparken. Medics were called but neither the ambulance drivers nor the police were willing to take him to

p. 169

hospital. The former were overheard to have said that the assailed man was a "damn pig” ("din jævla gris") who had "missed his chance" ("der mistet du sjansen din") due to the fact that he had lost control of his bladder and urinated on himself. The media reported that the victim was obliged to take a taxi to a doctor. He was subsequently transferred to hospital where he was treated for a cerebral haemorrhage.[46] This event was widely reported and generated a great deal of critical reaction, principally around whether or not this was a racist incident. The writer and former politician Anne Holt (born 1958) was left in no doubt. She concluded from the events of 6 August and the subsequent prevarication of the hospital leadership that "[r]acism has definitely taken root [in Norway], and it is so deep that we no longer recognise it" ("Rasismen har slått endelig rot, og det så dypt at vi ikke lenger kjenner den igjen”).[47] This incident has echoes of events some sixty-five years earlier in the same city. Now as then, it involves a fellow "countryman", a taxi, the Norwegian police and a cast of grey-zone characters. It could almost be a work by the artist Victor Lind, only he would have scripted it to take place on 26 November.

STUART BURCH

School of Arts \& Humanities

Nottingham Trent University

Clifton Campus

Nottingham NG11 8NS

United Kingdom

\section{ACKNOWLEDGEMENTS}

This article would not have been possible without the support of The Research Council of Norway (Norges forskningsråd), which funded a period of study at Oslo University in 2005. Victor Lind, Bill Niven and Lars Roede provided invaluable 
feedback on earlier drafts of this paper. That said, all views expressed in this article are the author's alone and are not necessarily endorsed by any of the people or institutions mentioned.

\section{NOTES}

[1] P. Levi, The Drowned and the Saved (London, 1988), p. 1. Quotations from this book will henceforth be signalled by (DS).

[2] One needs, of course, to exercise considerable caution when attempting to redeploy something that was specific to the "network of human relationships inside the Lagers" (DS, 23). Yet Levi himself invited just such an undertaking when writing that "in the Lager and outside, there exist grey, ambiguous persons, ready to compromise" (DS, 33; my italics). He moreover averred that "the time has come to explore the space which separates (and not only in Nazi Lagers) the victims from the persecutors” (DS, 5). What was pertinent in the late 1980s is still valid today. This is a motivating factor behind not only this article, but also the artworks by Victor Lind which it examines.

[3] A set of four video stills can be viewed as supplementary data online at http://fmls.oxfordjournals.org. (C) Victor Lind. Reproduced by kind permission of the artist.

p. 170

[4] The basis of Contemporary Memory - Who is Afraid? lies in a report of 27 November 1942 compiled by Karl A. Marthinsen (1896-1945), chief of the Security Police and State Police until his assassination on 8 February 1945. Entitled "Evacuation of Jews" (Evakuering av jøder), it is today (2007) available in full on a video monitor in the galleries of The Center for Studies of Holocaust and Religious Minorities (HL-senteret) in Oslo under an interpretative panel entitled "The Police arrest of Norwegians for annihilation" (audio section 130).

[5] A very similar operation to that carried out in November had occurred at 5.30 in the morning of 26 October 1942. It resulted in the arrest of 260 Jewish men who were then transported to various concentration camps in Norway. The action that took place in the early hours of 26 November focused on the remaining women and children. Their arrival at Oslo harbour was timed to coincide with the influx of Jews who had until then been held in the camps, such that by the time the ship Donau departed it is believed to have been carrying 532 men, women and children. See S. Abrahamsen, Norway's Response to the Holocaust: A Historical Perspective (New York, 1991), pp. $110-11$.

[6] STAPO was formed following the reorganisation of the police department in March 1941. It became its political wing, separate from the regular police and almost entirely staffed by members of the Nazi party. See "Statspolitiet" in: Norsk krigsleksikon 1940-1945, ed. H. F. Dahl (Oslo, 1995), available at http://lotus.uib.no/norgeslexi/krigslex/s/s.7.html\#statspolitiet (last accessed 13 August 2007).

[7] J. Sandven, “Sterkt om Norges rolle i Holocaust”, 8 January 2004. Source: http://intsos.no/?id=661 (last accessed 12 August 2007).

[8] These two designations - collaborator and traitor - allude to the definitions of the noun "quisling” in The Oxford English Reference Dictionary, ed. J. Pearsall \& B. 
Trumble (Oxford, 1996), p. 1184: “1. A person cooperating with an occupying enemy; a collaborator or fifth-columnist. 2. A traitor." The word derives from the surname of Vidkun Quisling (1887-1945), a figure referred to later in this article. [9] O. Kobbeltveit, “Nazist og jøssing”, Bergens Tidende, 27 February 2007, p. 2. One recent source speculates that Rød could have been a racist who aspired to shape a Norway populated by “pure Norwegian people”. The Nazi ideology might have served to fulfil this objective, meaning that he was simultaneously against both the Jews and the Germans. See Anon., "Knut Rød: Hvordan ble Rød påvirket av samtiden?” Source: http://www.hlsenteret.no/248/267/2072/Knut_Rod.pdf (last accessed 12 August 2007).

[10] Uncertainty about the extent of Rød's support for Milorg, his unwillingness to be "formally" identified with the Resistance movement, and the vested interests of those that spoke in his defence at his trial are all raised in Victor Lind's Contemporary Memory - Who is Afraid?.

[11] Rød handed in his notice in August 1943. His contract of employment ended in September, the same month that he resigned from the Nazi party, of which he had been a member since 4 January 1941; see Anon., "Knut Rød: Hvordan ble Rød påvirket av samtiden?”.

[12] The notion of teachers and students being rounded up is not at all unrealistic, as is apparent from a plaque on the steps of the main building of Oslo University (Karl Johans gate 47). Entitled “The German students", it explains that Oslo University was closed during the Nazi occupation and on 30 November 1943 - almost exactly one year after the departure of the Donau - some 650 students were deported to Germany, where they remained imprisoned until April 1945 ("TYSKLANDSSTUDENTENE // UNIVERSITETET I OSLO / BLE STENGT AV / DEN TYSKE OKKUPASJONSMAKTEN / 30. NOVEMBER 1943 // 650 STUDENTER / BLE DEPORTERT TIL TYSKLAND / OG SATT I FANGENSKAP / TIL APRIL 1945”). [13] For the term "parallel histories”, see C. Skeide, "Contemporary Memory - Who is Afraid?”, in: Hjerte og forstand: Festskrift til Victor Lind, ed. P. B. Boym \& A. van der Hagen (Oslo, 2000), p. 48. Source: http://www.kunst.no/fest (last accessed 12 August 2007). The video stills can be viewed as supplementary data online at http://fmls.oxfordjournals.org. (C) Victor Lind. Reproduced by kind permission of the artist.

[14] Cited in E. Moe \& R. Martinussen, "Kontroversielt kunstverk”, NRK, 21

December 2004. Source: http://nrk.no/nyheter/kultur/4367149.html (last accessed 12 August 2007).

[15] Lind produced this work in collaboration with Snorre Ytterstad and with support from the Fond for lyd og bilde and The Center for Studies of Holocaust and Religious Minorities (HL-senteret).

[16] All translations from the pedestal inscriptions are provided by the artist through the leaflet Gjerningsmannen (The Perpetrator) produced by The Center for Studies of Holocaust and Religious Minorities (HL-senteret). Celan's poem is translated by John Felstiner.

[17] Extract from the District Court sentence, 9 April 1948. The English translation is taken from the aforementioned leaflet, Gjerningsmannen (The Perpetrator).

p. 171

[18] K. Sverri, "Landssvikoppgjørets merkeligste rettssak”, Lov og Frihet: Festskrift til Johs. Andences på 70 årsdagen 7 september 1982 (Oslo, 1982), pp. 345-56. 
[19] The earliest of Lind's works connected to "the crucial year, 1942" dates from 1994. There is no space to discuss them all here, but I intend to do so in a subsequent paper.

[20] Cf. B. Kolsrud Jåsund \& K. Vold, "Holocaust-senter vurderer nazi-skuld”, NRK, 1 November 2005. Source: http://nrk.no/nyheter/kultur/5193070.html (last accessed 12 August 2007). One could well imagine that, should Lind have opted to monumentalise Knut Rød as a grey-zone character, he might have chosen to depict him as a carefully coiffured man in a dress suit; a neat, if rather banal-looking character who, from the vantage point of his office desk, determined the fate of hundreds of people.

[21] E. M. Bugge, “Problematisk monument”, 16 March 2006. Source: http://kunstkritikk.no/kk/anmeldelser_comments.php?id=729_0_21_0_C (last accessed 12 August 2007).

[22] J. E. Young, “The Counter-Monument: Memory Against Itself in Germany”, Critical Inquiry 18:2 (1992), 267-96 (p. 271).

[23] N. Lupu, "Memory Vanished, Absent, and Confined: The Countermemorial Project in 1980s and 1990s Germany”, History and Memory 15:2 (2003), 130-64 (p. 142).

[24] C. Dean, The Fragility of Empathy After the Holocaust (Ithaca \& London, 2004), pp. 5-6.

[25] One indication of this success is the fact that Tommy Olsson, the guest editor of Norsk Kunstårbok 2006 (Norwegian Art Yearbook 2006), Vol. 15, chose to put Lind's monument on the cover. It was his way of countering those "people that think art is a kind of barren island utterly isolated from the rest of the world" (p. 9). Another token of achievement came on 29 May 2007 when Lind was awarded the Oslo Bys Kunstnerpris 2006 for his "brilliant contribution to the art life of Oslo" ("for fremragende innsats innen Oslos kunstliv").

[26] Information derived from an interview between Victor Lind and the author, which took place in Oslo on 6 August 2007.

[27] This phrase is used by Lupu to critique Horst Hoheisel's countermonument in Kassel. See Lupu, “Memory Vanished, Absent, and Confined”, p. 155.

[28] Lupu, "Memory Vanished, Absent, and Confined”, p. 143.

[29] "No one kneads us again out of earth and clay,/no one incants our dust. No one./Blessèd art thou, No One./In thy sight would/we bloom./In thy/spite.//A

Nothing/we were, are now, and ever/shall be, blooming:/the Nothing-, the/No-One'sRose.//With/our pistil soul-bright,/our stamen heaven-waste,/our corona red/from the purpleword we sang/over, O over/the thorn.” Source:

http://www.nortonpoets.com/ex/celanp.htm\#psalm (last accessed 21 March 2007). The original German reads Psalm (1963) "Niemand knetet uns wieder aus Erde und Lehm,/niemand bespricht unsern Staub./Niemand.//Gelobt seist du, Niemand./Dir zulieb wollen/wir blühn./Dir/entgegen.//Ein Nichts/waren wir, sind wir, werden/wir bleiben, blühend:/die Nichts-, die/Niemandsrose.//Mit/dem Griffel seelenhell,/dem Staubfaden himmelswüst,/der Krone rot/vom Purpurwort, das wir sangen/über, o über/dem Dorn.” Source: http://www.lyrikwelt.de/gedichte/celang1.htm (last accessed 21 March 2007).

[30] This is not to overlook the fact that when the monument was first exhibited at Bomuldsfabriken Kunsthall in Arendal (4 March - 2 April 2006) it was accompanied by archival documents relating to Marta Leimann, born in Oslo on 10 September 1895 and murdered at Auschwitz on 1 December 1942. The documents included a copy of a letter signed by Knut Rød in which he rejects a claim that Marta Leimann was in 
fact a Swedish citizen. Rød concluded that she was a Norwegian and for that reason was transported on the ship Donau in November 1942 ("hun er norsk statsborger og av denne grund ble hun den 26/11-42 anholdt og samme dag sendt med D/S Donau”). This, and the case of Kathe Lasnik outlined below, provides a jarringly stark contradiction of the claim made at Rød's trial that he "all the time [...] assist[ed] his countrymen".

[31] J. Sandven, “Sterkt om Norges rolle i Holocaust”, 8 January 2004. Source: http://intsos.no/?id=661 (last accessed 12 August 2007).

[32] R. Helgheim, "Eit levande minne om Kathe Lasnik”, Dag og Tid, no. 47, 22 November 2003. Source: http://www.dagogtid.no/arkiv/2003/47/kathe.html (last accessed 12 August 2007).

[33] J. Sandven, "Sterkt om Norges rolle i Holocaust".

[34] S. Abrahamsen, Norway's Response to the Holocaust, pp. 95-6.

[35] “Jeg er en av dere, dere gjør vel ikke meg noe?”, in: E. Søbye, Kathe, alltid vœrt i Norge (Trondheim, 2005), p. 8.

[36] Lupu, “Memory Vanished, Absent, and Confined”, p. 157.

p. 172

[37] One other example might be the Harburg Monument against Fascism (1986) by Jochen \& Esther Shalev-Gerz. This monument is discussed in detail by Richard Crownshaw in his article "The German Countermonument: Conceptual Indeterminacies and the Retheorisation of the Arts of Vicarious Memory”, which appears in this Special Issue. Reference to the monument is also made by Paul Williams in "The Afterlife of Communist Statuary: Hungary's Szoborpark and Lithuania's Grutas Park”, also in this issue.

[38] For an earlier use of this concept, see S. Burch, "Space tuner: sculpture as catalyst in the work of Antero Toikka”, in: Ajan Tila - Space of Time: Sculptures 1981-2004, ed. O. Kantokorpi (Helsinki, 2004).

[39] The exhibition was held at Bomuldsfabriken Kunsthall in Arendal (4 March-2 April 2006).

[40] J. E. Young, “The Counter-Monument: Memory Against Itself in Germany”, p. 273.

[41] This was confirmed to me in confidence by an employee of The Center for Studies of Holocaust and Religious Minorities during a meeting in June 2007.

[42] M. de Certeau, The Practice of Everyday Life (Berkeley, Los Angeles \& London, 1984), p. xix.

[43] Two other interesting potential sites have been suggested by Tommy Olsson: either outside the main entrance to the Storting (Norway's parliament) or in the square fronting Oslo’s main railway station. The latter “would allow him [Knut Rød] to salute new arrivals, putting them in the right mood before they continue their way up Karl Johan [street], past the Nigerian prostitutes, the Rumanian beggars and the Norwegian junkies who stand around in the sunshine like living degrees of frost. For there is no reason to ignore facts, and the fact is they can be swept away with a summary stroke of the pen. And so can any of us"; T. Olsson, "Here come the warm jets: Norwegian contemporary art - the next episode”, Norwegian Art Yearbook 2006, Vol. 15, p. 10.

[44] See "The Nobel Peace Center - A Place of Peace". Source: www.norway.org/policy/peace/center/center.htm (last accessed 29 April 2006). [45] de Certeau, The Practice of Everyday Life, p. xix. 
[46] See G. Engesvik \& A. Nejad, “Sannheten skal frem”, Aftenposten, 10 August 2007, 2-3. At the time of writing (12 August 2007), Ali is in a coma.

[47] A. Holt, "Tragedien i parken”, Aftenposten, 10 August 2007, section "Kultur”, 4.

\section{FIGURES}

Figure 1: Video still from Contemporary Memory - Who is Afraid?, by Victor Lind. The National Museum of Art, Architecture and Design, Olso. See http://www.nationalmuseum.no. (C) Victor Lind. Reproduced by kind permission of the artist.

Figure 2: Monument to Knut Rød (The Perpetrator), by Victor Lind. The Center for Studies of Holocaust and Religious Minorities (HL-senteret), Oslo. (C) Victor Lind. Reproduced by kind permission of the artist.

Figure 3: The Nobel Peace Center, Oslo. Photograph author's own.

\section{SUPPLEMENTARY DATA}

Supplementary data can be found at FMLS online, http://fmls.oxfordjournals.org. 